\title{
History of Mirabilis expansa (Ruiz and Pav.) Standl.; Growth and Use in the Andes
}

\author{
Miriam Kritzer Van Zant \\ Department of Plant, Soil and Agricultural Systems, Southern Illinois University, Carbondale, IL 62901, USA
}

Received: April 9, 2016 / Accepted: May 2, 2016

\begin{abstract}
Several documents concerning the history and growth of $\mathrm{Mi}$ rabilis expansa (Ruiz and Pav.) Standl. (Nyctaginaceae), were found to be available by 2012 on international library and agency websites from South America. These documents, written in Spanish, had previously been difficult for this author to find in North America. Information in these documents and from additional papers and reports referenced in them, made it possible to summarize here what had been known historically about $M$. expansa. Modern research in Andean universities and agencies, completed but not seen by us prior to doing our research on $M$. expansa in southern Illinois, is included in the summary. Several points are covered in this material, including ideas on the origin of the crop, a list of indigenous names for the crop, and general descriptions of the appearance of several unnamed crop morphotypes grown in Peru, Ecuador and Bolivia. This information is considered relative to the appearance of and growth data from two crop morphotypes grown in southern Illinois. Additionally, there is information from the South American documents on ecological considerations for M. expansa in Latin America, germplasm information, how the crop has been grown traditionally, preparation of roots and stems for consumption including reduction of astringency and use in traditional dishes and for animal feed, and use of the leaves for fodder. Brief consideration is given here to invasive and rare Mirabilis spp. and how this relates to introduction of $M$. expansa into new locations, along with information on disease and pests known for the crop. Discussion includes our considerations for conservation of the crop, and comparison of Andean crop yields with published yield data for comparable crops grown in the United States.
\end{abstract}

* Corresponding author: mkvzant@siu.edu

\section{Introduction}

M. expansa (Ruiz and Pav.) Standl. is a rare Andean crop plant grown for food and fodder in the highlands of Peru, Bolivia, and Ecuador. However, it is disappearing from cultivation in the Andes. The goal of this paper, is to present information that preceded our own research on the crop, and which may prove valuable for utilizing $M$. expansa in alternative cropping systems in the future. There were four objectives met in this paper. First was presentation of all information that we could find published on the crop, prior to our own research with the crop in southern Illinois (Kritzer Van Zant, 2016a,b), in one document and in English. Our second objective was to draw comparisons with two morphotypes of the crop used in our research in southern Illinois, with the M. expansa morphotypes described though unnamed in the previous literature. Morphotypes were not specified for most of the information presented in this paper. Information here is given for the crop at the species level except where otherwise stated. Descriptions of the morphotypes used in Latin America and in southern Illinois are based on the language used to described morphotypes in the earlier literature. For the third objective, information is added on whether or not there is a potential for the crop to become invasive, based on what is known about it and other Mirabilis spp. (Kritzer Van Zant, 2016a,b). The fourth objective is to show how the crop's root and forage yields compare with published information for similar uses of other crops and rangeland in the United States. Specifically, M. expansa root yields per hectare in the Andes (Rea, 1994) are compared with yields for potatoes grown in Idaho (Olsen, 2004). In addition, forage yields per hectare for M. expansa in the Andes (Seminario, 2000c, 2004b) are compared to forage yields from improved alfalfa in California (Putnam et al., 2007), and from unimproved rangeland in Utah (Perry, 2012). 
This crop is considered by us to be a subspecies of the wild type of M. expansa, based on Kritzer Van Zant's monograph of Andean Mirabilis, in preparation for publication. Detailed descriptions and precise Latin names for the two morphotypes that we have worked with in southern Illinois will be given in the monograph on the Andean species. For the present, the first initial of each intended name is utilized at the level of variety, var. ' $L$ ' and var. ' $T$ '.

Upon beginning field work on growing this endangered indigenous crop, little information was available to us, even after an extended period of taxonomic research on Andean Mirabilis. Several attempts were made by us earlier, to recover information about research in the Andes. Some of this work had been mentioned to us by Jaime Estrella (Estrella, personal communication, 1999), an Andean researcher associated with Centro Internacional de la Papa (CIP), based in Lima, Peru. Carlos Ochoa had also mentioned to us unpublished reports on $M$. expansa at CIP. Now it is clear that in the 1980's, renewed interest in preserving and understanding a number of indigenous Andean root crops resulted in research on M. expansa (Tapia, 1990; Seminario, 1993, 2000a, 2000b, 2000c, 2004a, 2004b; CIP, 1998; Lizárraga, 2000, 2004), primarily under the auspices of CIP. These documents, and certain other South American documents addressing research on $M$. expansa, have only recently become available in North America. This increase in availability is thanks to the practice of international university and research libraries digitizing much of their holdings and placing them on the internet. This has made in-house agency documents and others with limited circulation, easier to acquire by other libraries and individuals.

Availability of these particular documents on the internet came to our attention in 2012. Further, these documents also brought to our attention, through their bibliographies, applicable papers by others. Some of these secondary sources were perhaps available earlier, but their meaning for research described in Kritzer Van Zant (2016a) had previously been obscured. Therefore, results applicable to M. expansa, from CIP researchers and their collaborators are incorporated here along with information from the limited number of publications on these topics earlier known to us. We also include some of our observations from our own research in the Results, and offer our opinions on the implications of some of this research in Discussion.

\section{Methods}

Most of the documents on the growth and use of M. expansa were written in Spanish. To summarize them required translation into English by this author (Rea and León, 1965; Rea, 1982; Tapia, 1990; Seminario, 1993, 2000a, 2000b, 2000c, 2004a, 2004b; CIP, 1998; Seminario and Valderrama, 2004; Túpac Yupanqui, 2000; Lizárraga, 2000, 2004; Valderrama et al., 2004; Vásquez et al., 2004).

Though few of the internet-posted documents concerning $M$. expansa obtained by us from 2012 on, were published in peer reviewed academic journals, they include bibliographies which led us to other documents (Rea and León, 1965; Rea, 1982; Izquierdo and Roca, 1998; Tapia, 1990, 2007) on M. expansa.
These include papers published in academic journals. This review article examines this combined content and some of its implications.

\section{Results}

\section{Origin of $M$. expansa}

Julio Rea studied the crop in Peru, Bolivia, and Ecuador. Rea concluded that the Cajamarca region of Peru is the center of distribution and the origin source of mauka for Bolivia and Ecuador, spread by human migration during the Incan empire (Rea and León, 1965; Rea, 1982). This origin theory had been supported by the National Research Council of the United States since 1989 (Popenoe et al., 1989; Seminario, 1993). After studies of several traditional root crops during the 1980s, the origin theory for $M$. expansa was expanded. The place of origin of mauka in Peru may incorporate a region including Ancash, La Libertad, Cajamarca and Amazonas (Seminario, 2000a). Venezuela and Chile also have wild populations of $M$. expansa, but little exploration has occurred to find the crop in either nation, perhaps because botanical explorers there were interested in wild plants, while what is known about the crop for Bolivia, Ecuador and Peru was discovered by persons looking for agronomic information (Seminario, 1993).

\section{Indigenous names for $M$. expansa}

M. expansa is known by numerous indigenous names including: miso and tazo in Ecuador; mauka in Bolivia and Peru; and achagu, chago, chagos, chaco, shago, cushpe, cushpín, cushpenes, siguas, arricón, arracacha de toro, yuca Inca, yuquilla, camotillo, pega-pega (beat-beat), rabanito, shalca yuca and yuca de jal$\mathrm{ca}$, in a variety of indigenous languages and dialects (Popenoe et al., 1989; Tapia, 1990; Sperling and King, 1990; Seminario, 1993, 2000a, 2000c, 2004b; Flores et al., 2003; Ugent and Ochoa, 2006). Rabanito is also an indigenous name for cultivated radish, Raphanus sativus L. (Brassicaceae) (Seminario, 1994, 2000c). Adjectives for color are often part of common names for varieties of the crop, added to the local name for the crop as a whole (Seminario, 1994, 2000c, 2004b). A long list of common names for this crop indicates a long-term relationship between M. expansa and humans (Seminario, 1994, 2000c, 2004b). Apichu, the Quichua name for the $M$. expansa crop, is more often applied to camote (Ipomea batatas (L.) Lam. (Convolvulaceae) (Seminario, 2000c, 2004b). Duel use of names like rabanito and apichu reflect how $M$. expansa can be confused or lumped with other roots, and like it's cousin, M. jalapa L., mistaken as a member of the family Convolvulaceae (Kritzer Van Zant, $2016 \mathrm{~b}$ ).

Wild mauka in Bolivia can be called: Llaki llaki, mauka, and sacha mauka (Seminario, 2000c, 2004b). In northern Peru, wild mauka is known as camotillo, pega pega, pegajera, or papelilla (Seminario, 2000c, 2004b). In Ecuador, the wild type is called moradilla or pega pega (Seminario, 2000c, 2004b). Names for M. expansa vary with particular ethnic groups and populations (Seminario, 2000c, 2004b). 
Appearance of M. expansa in the Andes and of Andean Material Grown in southern Illinois

Bolivian roots have been reported as being salmon-colored (Rea and León, 1965; Popenoe et al., 1989; Tapia, 1990). Yellow and white roots are also reported from Bolivia, growing at altitudes of 3200-3500 m (Rea, 2000). Roots can also be yellow to cream-colored (Seminario, 1993). New collection of mauka from Cajamarca, Peru, was reported by Seminario (1993) from 1984 along with donations of a form of white chago by campesinos. Campesinos are primarily subsistence farmers, and frequently culturally indigenous people. These campesinos reported that their grandparents had grown the plant (Seminario, 1993). In comparison, Var. 'L' sent for research purposes to southern Illinois from Peru (Kritzer Van Zant, 2016a) produces a root with either a turmeric or salmon-colored epidermis, and an off-white starchy interior. Var. ' $T$ ', brought to southern Illinois from Ecuador by Miriam Kritzer Van Zant, has a light-tan epidermis and a yellowish to off-white starchy interior.

Three morphotypes were described for the crop for northern Peru from the conserved collection of chago roots in Cajamarca (Seminario, 2000b). The three morphotypes all have decumbent habits, though the purple stemmed morphotype is the most decumbent (Seminario, 2000b).

Varieties ' $L$ ' and ' $T$ ' were both decumbent to the same degree at the end of the growing season outdoors in southern IIlinois. However, var. ' $L$ ' spread out more quickly than var. ' $T$ ' as they grew in southern Illinois. Also, plants were not field grown in southern Illinois for as many months as in the Andes.

Other morphotypes have stems described as dark green and yellowish-green, respectively (Seminario, 2000b). The purple stemmed morphotype has lilac-colored conical flowers, with dark green cordate leaves with purple blotches or spots, a yellowish cream-colored root epidermis and cream-white root interiors, and is ready for harvest between the other two (Seminario, 2000b). The dark green stemmed morphotypes have green to dark green ovate leaves, fusiform-conical flowers which are white with lilac-colored pigmentation, and a yellowish-cream colored root epidermis and cream-white root interiors (Seminario, 2000b). The dark green morphotype is ready for harvest later than the other two morphotypes described by Seminario (2000b). The morphotypes with yellowish-green stems have cordate clear green leaves, conical white flowers, roots with white interiors, and are the earliest of the three (Seminario, 2000b).

Each of these descriptions contains slightly different combinations of characters than would apply to var. 'L'. Var. 'L' has purple flowers, splotchy dark green stems and leaves, and turmeric-colored root exteriors. Var. 'L' seed was sent to us by CIP and is probably a different accession than those described in Seminario (2000b). Var. ' $T$ ' appears close to the description of the morphotype with yellowish-green stems. However, var. ' $T$ ' has pale, splotchy, slightly yellowish green leaves and stems, which seems to be different than "clear green leaves", so it may also be a different accession than the ones above. Var. ' $T$ ' was collected by us from an Ecuadorian farmer with permission from the government of Ecuador.

\section{Germplasm of M. expansa}

There were up to 35 cultivars in live germ plasm banks in Peru as of 1994, three of those accessions were kept separately from the others, all in Cajamarca (Rea, 1994).

Valderrama and Seminario (2004) state that there were 56 chago collections in 2000 at UNC (Universidad Nacional de Cajamarca). This was after a search was made for germplasm in 22 provinces and 56 districts in northern Peru, and before ten cultivars of chago were lost during the 1997-1998 El Niño event (Seminario and Valderrama, 2004; Valderrama and Seminario, 2004). This El Niño event caused soils to be more damp than usual in Cajamarca (Seminario and Valderrama, 2004; Valderrama and Seminario, 2004). In 1991, two chago cultivars were returned to a farmer growing a third variety in Huamachuco, Peru (Seminario and Valderrama, 2004).

In 1994 and 1995 chago was returned along with three other species to the farm communities of Pariamarca and Chetilla (Seminario and Valderrama, 2004). These communities later provided duplicate material to replace some entries lost in the 1997-98 El Niño event (Seminario and Valderrama, 2004). In total 16 locations, 56 entries, 13 farmers, three morphotypes and 36 kilos of seed were involved in the repatriations for chago, though the emphasis of the program was switched to arracacha, which had greater familiarity for the farmers (Seminario and Valderrama, 2004). In addition, three collections of chago were found in Peru in 2000. All three were wild types (Valderrama and Seminario, 2004), and are described in the section above. DNA work, however, indicates there may be many fewer cultivars (Chia et al. 2006). Chia et al. (2006) looked at 37 Peruvian accessions for the M. expansa crop, using 31 RAPD markers, and concluded there may be only eight genetic variants among the 37 accessions examined. RAPD cannot distinguish epigenetic variants. Though accession numbers are given (Chia et al., 2006) neither describes the visual or other kinds of distinctions among their morphotypes. Chia et al. (2006) also do not say whose morphological concepts of taxa were initially followed, though they claim to have improved on these unspecified concepts for identification of $M$. expansa varieties.

Cytogenetic studies indicate that somatic chromosomes in $M$. expansa number 58, with $\mathrm{n}=\mathrm{X}=29$ chromosomes (Seminario, 2000b), however there has been much discussion of ploidy variation in Mirabilis in the literature (Kritzer Van Zant, 2016a).

\section{Ecological Information Relevant to the Growth of M. expansa}

Lomas are patches of built up soil, from succeeding generations of mist-adapted vegetation where there is little rainfall. $M$. expansa cultivated varieties were grown in South America in the tough growing conditions of lomas patches within hot sand desert, found on the Peruvian coastline. M. expansa is also known to grow in very high altitude cold deserts, known for their volcanic soils, in particular the Paramo regions in the Andes. Known climates and locations for growth of $M$. expansa in the Andes are given in several sources (Rea, 1982, 1994; CIP, 1998).

Extensive root systems and long duration of growth make $M$. expansa a good erosion control species (Rea, 1982; CIP, 1998). 
Use of M. expansa for erosion control makes sense for Mirabilis, not in terms of root systems but of rhizomes, which send runners far into the ground. When M. expansa roots were dug up at harvest time in southern Illinois, they came up fairly easily from the sand with a pitchfork. However underground rhizomes always broke off, and from their diameter and tendency to taper gradually, it appeared that they could easily extend down to the water table a few feet below. M. macfarlanei Constance and Rollins (ODA, 2011), a rare endemic in the U.S. limited to Idaho and Oregon, has been reported to have roots typically under $2 \mathrm{~m}$ in length which can extend down as much as $10 \mathrm{~m}$. Observation of $M$. expansa and M. jalapa, growing outside in southern Illinois, leads us to believe that the longer "roots" on M. macfarlanei, mentioned in ODA (2011), are actually underground rhizomes.

M. expansa is extremely drought resistant and can tolerate heavy rain. This has been observed in southern Illinois. However, both varieties utilized in southern Illinois research are intolerant of standing water. In southern Illinois it was observed that standing water invariably caused roots to quickly disintegrate, both in the greenhouse and outside. Var. ' $T$ ' in southern Illinois is slightly more vulnerable to water damage than var. ' $L$ '. Var. ' $T$ ' may also be more drought resistant than var. ' $L$ '.

Root disintegration in $M$. expansa, in standing water, occurs in spite of known resistance to some soil fungi. This resistance is due to Class I ribosome inhibiting proteins which have been extracted from the roots (Vivanco et al., 1997, 1999a,b; Vivanco and Flores, 2000).

In Cajamarca, conditions where the crop grows best are between $2300-3500 \mathrm{~m}$ in altitude, with average annual temperatures between $11-16^{\circ} \mathrm{C}$ (Seminario, 1993). M. expansa tolerates highest temperatures between $22-29^{\circ} \mathrm{C}$, and lowest temperatures between $4-7^{\circ} \mathrm{C}$, in deep soils with moderate texture and plentiful organic matter (Seminario, 1993).

Experiments took place in the Valley of Cajamarca with an average annual temperature of $14^{\circ} \mathrm{C}$, average precipitation of $680 \mathrm{~mm}, 73 \% \mathrm{RH}$, open clay-lime soils of $\mathrm{pH} 6.8$, at $2536 \mathrm{~m}$, and $7^{\circ} 10^{\prime} \mathrm{S}$ lat (Seminario, 1993). The crop also grows in black loose soils and sandy reddish soils in Cajamarca, both having plenty of organic matter (Seminario, 1993, 2004b). The plants are thought to have little sensitivity to day length (Seminario, 2004b), and this has not been contradicted in southern Illinois. Native clay soils in southern Illinois are too wet and heavy to grow the crop. A typically high water table in southern Illinois may also be a factor.

Mauka is grown between 2400 to 4300 meters according to Flores et al. (2003). Izquierdo and Roca (1998) place the crop at $2500 \mathrm{~m}$. Tapia $(1990,2007)$ puts altitudes for M. expansa between 1000 and $2500 \mathrm{~m}$ in altitude. Seminario (1994, 2004 b) both expands the range of altitudes known for the crop and breaks it down by country. In Ecuador, the plant has been found between 2700-3100 m. Var. ' $T$ ' was found by Kritzer Van Zant in an agricultural field in Pichincha province of northern Ecvador, near the road to the Tocacachi Ruins, at $2760 \mathrm{~m}+/-140 \mathrm{~m}$ [Garmin GIS]. In Bolivia, Seminario (1994, 2004b) places M. expansa between 2900-3500 m for cultivars, and 2100-2500 $\mathrm{m}$ for wild types. In Peru, altitudes are between 2900 and 3300 $\mathrm{m}$, while in northern Peru plants occur between 2500-3400 m
(Seminario, 1994, 2004b). Plants are also said to prefer neutral $\mathrm{pH}$ soils, and have been found growing at temperatures typically at $13-14^{\circ} \mathrm{C}$, between extremes of $5-25^{\circ} \mathrm{C}$ (Seminario, 1994, 2004b). In southern Illinois July and August temperatures can reach $43^{\circ} \mathrm{C}$, and frequently remain near $37^{\circ} \mathrm{C}$ for more than a week at a time.

A sowing experiment in Texcoco, Mexico resulted in plants that persisted without flowering for 1.5 years at an altitude of $2250 \mathrm{~m}$, causing researchers to suspect that the crop can only complete its life cycle in the central Andes (Seminario, 1993, 2004b).

Plants flowered but did not seed in the greenhouse in southern Illinois. At least six years passed before seed grown plants of var. ' $L$ ' and its subsequent clones, commenced flowering in southern Illinois. Rhizome grown material of var. ' $T$ ' began flowering in the greenhouse within a year of arriving in southern Illinois. However, flowering has been very irregular in the greenhouse since, sometimes not occurring at all for more than one year, then re-occurring, with little seasonal correlation. We've never seen flowering in the field for either variety in southern Illinois.

\section{Mirabilis spp. can be Rare or Invasive}

Neither cultivar has successfully wintered over outside in southern Illinois. No special efforts were made there to cover or otherwise protect them. They do survive freezing temperatures in the Andes. Perhaps this has to do with the size of the roots, degree of establishment, and depth of the water table. Neighbors, living in the town where the owners of the rural property where var. ' $T$ ' was collected also live, told Kritzer Van Zant that there were dormant roots of the crop growing underground in the dirt path alleyway which ran behind their homes, though there was no evidence of the plants above ground. This level of dormancy is similar to what established storage roots of North American prairie plants can do during droughts, particularly in winter.

Rare endemic from the western US M. macfarlanei, invasive tropical $M$. jalapa, and sometimes invasive midwestern $M$. nyctaginea (Michx.) Macmill. are discussed in Kritzer Van Zant (2016b). This information indicates that no blanket statement can be issued concerning invasiveness for Mirabilis.

Farmers in Humachuco are said to not still grow M. expansa much because it becomes very aggressive (Seminario, 1993). In addition, $M$. expansa is thought to be competitive with maize, diminishing its growth, and possibly a reason that it has become less popular for cultivation in modern times (Seminario, 1994, $2004 b$ ). However, other problems with growing M. expansa may indicate that aggressiveness is not the major reason that the crop is disappearing in the Andes.

\section{Additional Problems for Growing M. expansa}

Some farmers say they only grow a small amount of $M$. expansa for themselves because of the lack of a market for the crop (Seminario, 1993). Seeds are also in short supply (Seminario, 1993). Problems with chago, as well as with a number of other indigenous food crops, include weight loss during process- 
ing and handling. Chago is also at risk for damage including breakage or cutting of the roots during harvest (Túpac, 2000), and stems during cultivation (Seminario, 2000c). Vines of both varieties grown in southern Illinois became fragile as they became longer and as stems became thicker and denser in number. Stems broke easily when disturbed by late summer (Kritzer Van Zant, 2016a).

Though natural conditions do not allow for long term storage of chago, these roots store better than those of yucca or arracacha (Túpac, 2000; Seminario, 2004b). Long term storage of fresh roots is difficult (Seminario, 2000c).

\section{Known Agricultural Companions for M. expansa}

M. expansa is thought to have been grown traditionally with corn (Seminario, 1993). M. expansa is frequently grown with other crops, including corn (Zea mays L.), beans (Phaseolus vulgaris L.), squash (Cucurbita ficifolia Wall. or Bouché), and other cultivars of beans and squash, as well as being associated with other ancient crops including arracacha (Arracacia xanthorrhiza Bancr.), llacón (Smallanthus sonchifolius (Poepp. \& Endl.) H.Rob.), potatoes (Solanum tuberosum L.), tarwi (Lupinus mutabilis Sweet or Lindl.), and occasionally appearing spontaneously with wheat (Triticum vulgare Vill.) (Seminario, 2000c, 2004b). IPNI (2012) show the author of C. ficifolia both as Wall. 1832, and Bouché 1837. So, they may not be the exact same squash species. IPNI (2012) gives the author of Lupinus mutabilis as Sweet 1830, and Lindl. for both 1539 and 1832, so either one is a synonym of the other, or they are also not the exact same species. M. expansa is also occasionally mono-cropped, and can be found with diverse weeds on fallow land (Seminario, 2000c, 2004b).

\section{Agricultural Research on M. expansa in the Andes}

Agriculture developed in the Andes in dry inter-Andean valleys, when the techniques for irrigation were discovered, predating agriculture in humid areas of the same region (Tapia, 1990). Initially, cultivation of M. expansa was described only for Bolivia and Ecuador (Rea and León, 1965; Rea, 1982; Popenoe et al.,1989; Tapia, 1990). Cultivation of M. expansa is thought to be a very old practice, though there is no published archeological record of this (Seminario, 2000a). In Ecuador, Bolivia and Peru, farmers with small operations incorporate M. expansa into systems of mixed farming and polycultures (Seminario, 2004b).

In the Andes, propagation is usually done utilizing stem pieces (Rea, 1994). Traditional propagation of mauka in Bolivia was done clonally from basal buds or stem or shoot pieces (Rea and León, 1965). However, seed growth is possible (Rea 1994; Rea and León, 1965). Plants grown from basal buds or seed require about one year before harvest, while plants grown from shoots take a little longer (Rea and León, 1965).

Var. 'L' was propagated from seed in southern Illinois, and since propagated from stem cuttings of two surviving F1 plants and their vegetatively cloned descendants. Var. ' $T$ ' has been propagated vegetatively since it arrived in Illinois from Ecuador. In the Andes plants are typically grown a year or longer, with plants started in furrows in $1 \times 1 \mathrm{~m}$ holes (Rea, 1994). Production typically takes seven to nine months (Rea, 1994). This is a longer growing season than what is typically available in temperate North America.

Seed grown plants of $M$. expansa in the Andes emerge in 4-6 days, first leaves emerge between 6-9 days, and tuberization occurs 25-30 days after first leaves emerge (Seminario, 1993). Seed to harvest is about 225 days, and next generation seeds appear 250-280 days after sowing (Seminario, 1993).

Floral buds of this Andean grown M. expansa appear 7080 days after tuberization, another 25-30 days are needed to achieve anthesis, and from anthesis to the commercial harvest stage is 90-100 more days (Seminario, 1993). Timing was also broken down separately for the three northern Peruvian morphotypes. The purple stemmed morphotype took 200-215 days from sowing to production of floral buds, and 19-25 days from production of flower buds to anthesis (Seminario, 2000b). The dark green stemmed morphotypes took 225-230 days from sowing to production of floral buds and an additional 2227 days to anthesis (Seminario, 2000b). The yellowish-green stemmed morphotypes took 225-228 days from sowing to production of floral buds and 20-28 more days to anthesis (Seminario, 2000b).

Plants were said to be propagated with ease in the Andes, from underground stems, stem cuttings, and lateral shoots (Seminario, 1993, 2000c, 2004b). Franco and Rodriguez (1988*) reported shoot stems gave $71-97 \%$ of the expected productivity in evaluation trials (Seminario, 2004b). In a bed made from reeds (Arundo donax) (Poaceae) and filled with sand, beginning with stem cuttings and lateral shoots, roots appeared in 22 days, plants were ready for transplant 23 days after rooting, $96 \%$ of cuttings rooted, cuttings each produced $9-37$ roots, and roots had reached lengths of $3-12 \mathrm{~cm}$ by the time of transplant 45 days after starting (Seminario, 1993, 2000c, 2004b). IPNI (2012) has A. donax L. 1753, and A. donax Georgi 1780, it is unclear to us if they are the same species. Ninety-six percent of cuttings root in the Andes, and 23 roots typically develop from each cutting (Rea, 1994). It is not clear to us whether Rea (1994) meant 23 root segments per root mass, or whether runners establish separate root clusters. In indigenous plots, most plants produce two to five roots (Rea, 1994). Seven month old plants were evaluated in Peru, revealing an average of 266 stems per plant, each with four nodes or eight buds (Seminario, 2000c, 2004b).

Plants are arranged about $80-100 \mathrm{~cm}$ between furrows and $40-60 \mathrm{~cm}$ between holes dug for individual plants in fields (Seminario, 1993). Plants can also be given a head start to the bud stage in the greenhouse (Seminario, 1993). Another method is to harvest the roots, and then put the crowns back into the same ground, also sometimes wells are dug in the ground, crowns set in them, and soil is used to cover the crowns (Seminario, 2004b). Crown no doubt refers to the transition zone between root and shoot. The precise meaning of 'wells' was unclear in translation. Perhaps wells just means holes, or perhaps this refers to areas of loosened or otherwise prepared soil.

Natural sowing is done by allowing seed to fall to the ground to germinate with the first rains, the beds being thinned out later (Seminario, 2004b). Evaluations were completed for ten entries 
of chago, maintained in one location for two years each at UNC (Valderrama and Seminario, 2004).

Plants of $M$. expansa that do not get harvested, generally drop their leaves and go dormant in winter, reappearing as fresh shoots from surviving roots the following spring (Seminario, 1993; Valderrama and Seminario, 2004). Though above ground growth is considered cold intolerant, $M$. expansa is more resistant to cold than achira or yacón (Seminario, 2004b).

Anthesis means floral opening. Flowers, apparently for all three northern Peruvian morphotypes, open only once in Cajamarca, beginning to open at 5:30 pm, and beginning to close at 10:30 am (Seminario, 2000b). These plants are fully open at 9:30 am and fully closed by 12:15 pm, for a total anthesis of six hours and 45 minutes (Seminario, 2000b). Wild type flower anthesis is one or two hours longer (Seminario, 2000b). Thus, the cultivars are true four o'clocks. The three morphotypes are thought to mostly self-pollinate, with several insects acting as secondary pollinators (Seminario, 2000b). Tuberization begins early whether plants are started from seed or are vegetative clones, with primary roots thickening within 30 days from sowing (Seminario, 2000b). Flowering typically occurs after 100 days with another 100 days to harvest (Rea, 1994). However, harvest has also been reported to occur when plants are seven to eight months old, when flowers begin to wilt (Túpac, 2000).

None of the plants grown in southern Illinois flowered outside though after several years annual flowering did commence in the greenhouse and continued for several years, even occurring in var. ' $L$ ' plants started in the same year from cuttings that had already flowered. Rhizomes from Ecuador of var. ' $T$ ' flowered in the greenhouse their first year in southern Illinois. Flowering eventually stopped occurring with any regularity, until the plants died a few years later (Kritzer Van Zant, 2016a).

Based on $90 \%$ survival, and sowing distance of $0.80 \times 0.50$ $\mathrm{m}$, it was concluded that 103 seven-month old mother plants, would be needed to plant one hectare of chago (Seminario, 2000c, 2004b).

In the Andes weeding and cultivation are usually done 2-2.5 months after sowing and again after four months, with care needed not to break the fragile stems (Seminario, 2004b). In the same series of papers, a table describing the handling of germplasm in the Andes for four indigenous crops appears twice. Information in the chart for chago (M. expansa) addresses use of shoots or underground stems for vegetative propagation, seed propagation and planting in furrows. Distance between furrows and plants, is given as $0.70 / 0.60 \mathrm{~m}$. Information is presented in a chart for ten entries, on three weedings, one cultivation, three irrigations, one pruning, the cutting of roots and vines, pests present, the lack of diseases, the lack of applied organic fertilizer, and growth of a crop grown 9-1 2 months (Vasquez et al., 2004; Valderrama and Seminario, 2004). In southern Illinois, better harvest weights were obtained with bi-monthly weeding than with monthly weeding, and better results were obtained from monthly weeding than from only weeding at planting and mid-season.

Plants grown for two years must survive winter conditions at extremely high altitudes, and typically yield 0.5-2 kg roots, with a yield per hectare of 12-52 tons of roots while also typically producing $7 \mathrm{~kg}$ each of fodder (Rea, 1994). In the UNC trials, root yields for M. expansa spanned from $1.2-4.2 \mathrm{~kg}$ (Valderrama and Seminario, 2004).

In the previously described experiments in the Valley of Cajamarca, in fertile soil, at 25,000 plants/hectare, harvest weights of roots were $1.8-5.5 \mathrm{~kg} /$ plant or $45,000-137,000$ $\mathrm{kg} /$ hectare (Seminario, 2000c, 2004b). This much more densely planted Cajamarca experiment yielded about $1 / 3$ to $2 / 3$ the $\mathrm{kg} /$ hectare of roots compared with the less dense plantings reported above.

Harvest in the Andes is usually timed to wilting of flowers (Seminario, 2004b). Allowing plants to grow two years increases harvest yield with little loss of quality (Seminario, 2004b). It was not clear from this document if this referred to total or annual yield. It may mean both.

In Ecuador, plants of var. ' $T$ ' were seen by us in the field, reaching about one meter around and one meter high, with roots that penetrated the soil by about one meter deep. Rea (1982) notes this is the typical size of the plants in Ecuador and Bolivia, which are usually harvested after one year of growth for seed grown plants, though some stems may be left in the ground to create a crop for later harvest. Yet Rea (1994) has also said the crop needs 7-9 months to mature. Seminario (1994) clarified that plants derived from basal shoots require one year to mature, though plants can take longer if started from suckers, and 7-9 months is typical for production. They are biologically perennial but considered annual in terms of their use (Seminario, 2004b).

Seed of $M$. expansa stores for several years without much loss of viability, and seeds stored at $18^{\circ} \mathrm{C}$ lose viability at about $4 \%$ per year according to Peruvian studies (Seminario, 1993, 2000c, 2004b).

\section{Preparation of M. expansa for Food - Including Traditional Methods for Mediating Astringency}

There are reports of indigenous people curing $M$. expansa roots before eating them (Rea, 1982) and restricting human consumption to very young leaves. Chago is both said to be usually consumed fresh, and also after sun drying for a few days, to eliminate certain principal astringents (Túpac, 2000). Andean root crops, including oca (Oxalis tuberosa (Oxalidaceae) Molina), have been briefly sun-treated to sweeten them (Arbizu and Tapia, 1994, 1998). Astringency is a problem for marketing $M$. expansa, though less astringent varieties, such as those from Ecvador, and indigenous processing methods, may also increase palatability (Popenoe et al., 1989). Popenoe et al. (1989) stated that tubers of $M$. expansa are cured to sweeten them, giving them a similar sweetness to that of sweet potatoes.

Curing the roots is a simple process. Plants are either hung in a tree or buried in straw for eight days, and then roots are consumed like other root vegetables (Popenoe et al., 1989; Sperling and King, 1990, Seminario, 2000c). Pits have been dug for sweetening, containing layers of $M$. expansa roots, interlaid with layers of barley straw (Popenoe et al., 1989; Rea, 1982). If the roots depicted in these sources are full-grown, the pit could easily be 3-4 m deep. As mentioned above, var. ' $L$ ' can produce 
a turmeric-colored crystalline powder on the outside of the epidermis. The turmeric color and crystalline appearance are lost from roots on plants hung in a barn to dry, by the end of one week. This color change may correlate with another chemical change, making them safer to eat or more palatable. Though Rea (1994) indicates they are cured for sweetening, no experimental data is referenced by Rea to back this. Var. ' $T$ ' roots did not have turmeric colored powder on the epidermis, nor any similar substance which underwent an obvious color change, though the epidermes of all roots of both varieties were observed to darken slightly while drying in the barn.

Mauka can be parboiled and eaten like sweet potato and cassava in Bolivia, where roots also could be sweetened by sun drying to neutralize astringent components (Rea and León, 1965; Popenoe et al., 1989). In Peru, roots are said to be left out sometimes during the sunny hours (Seminario, 2004b). This perhaps means that they are not left out overnight, though this is unclear to us. Perhaps this wording means they are left outside and covered at night.

In Bolivia, stems and enlarged roots cured to eliminate astringent flavors can be cooked with sweeteners (Rea, 1994). Water left over is then consumed as a soft drink (Rea, 1994). Other sources include more specifics about preparation of this soft drink and also describe additional ways to use the plant. In more detailed reports, corn syrup, chancaca [brown sugar], or sugar, have been used to make roots more palatable to humans, the water in which the roots are boiled is served as a soft drink, while pigs are fattened with stems (Rea and León, 1965; Popenoe et al., 1989; Seminario, 2000c, 2004b). This may refer to enlarged stems. They have amino acid profiles similar to roots (Kritzer Van Zant, 2016a).

Roots were fed to domestic birds (Tapia, 1966* reported by Seminario, 2004b). M. expansa is used less frequently to fatten pigs, usually stems and roots are mixed with other crops for this purpose, though sometimes pigs are allowed to feed at will on post-harvest remnants in the field (Seminario, 2004b). In Ecuador, lard from pigs fed chago was said to be of good quality (Tapia 1966* reported by Seminario, 2004b). When feeding stems to animals, preference was seen for basal and terminal portions, probably due to the wealth of carbohydrates in the basal sections, which are more likely to be enlarged with starch, and for the smoother less fibrous texture of the upper parts relative to the middle sections (Seminario, 2004b). Cavies, also called cuyes, are Andean domestic guinea pigs. Whole plants are fed to pigs, cavies/cuyes, vicuna, sheep and cattle, which are partial to it (Rea, 1994, Seminario, 2000c, 2004b). Bolivian mauka has been shown to contain $4-7 \%$ protein (Rea, 1994). It seems this percentage is only for roots, based on research on protein content in collaboration with William Banz of Southern IIlinois University (Kritzer Van Zant, 2016a). This analysis of amino acids in the southern Illinois grown M. expansa (Kritzer Van Zant, 2016a), gives the first look at the amino acid components of $M$. expansa protein. The amino acid profiling work was presented along with results from preliminary testing for micro molecule toxicity by Hee-Byung Chai (Kritzer Van Zant, 2016a) in Douglas Kinghorn's laboratory at Ohio State University. Laboratory methods and data are not presented for most of the reports of protein content for M. expansa in the Andean literature, so those measurements may be of total nitrogen, not total protein.

Chago leaves can be used in a traditional technique, along with other greens, herbs and roots, to stuff a pig for roasting (Seminario, 2004a). In Ecuador, leaves are added to salads and chili sauces, and buried roots are allowed to sweeten in pits to concentrate sugars, producing one of the two basic edible forms, "sal" [salt] and dulce "sweet" (Rea, 1982, 1994; Popenoe et al., 1989; Seminario, 1994, 2000c, 2004b). Roots can also be served with fish and tomatoes (Seminario, 2000c, 2004b). In Ecuador, tuberized roots and stems are skinned immediately after harvesting, whether preparation continues for the "sal" or "dulce" form (Seminario, 2004b). Chago is also said to be usually consumed fresh, and also after sun drying for 2-3 days to eliminate certain principal astringents (Túpac, 2000). Though it was a little unclear in translation, this probably means the plants could be eaten after this short drying period. After peeling, roots are parboiled (Túpac, 2000).

In Peru, a carnival dish called sancochado containing large pieces of seasoned roots and meat, including yucca and sweet potato, can include mauka as well as chicken or pork and cabbage (Seminario, 2004a, 2004b). Sancochado is usually made at the time that cultivation and weeding of chago occurs (Seminario, 2004a). Roots can also be parboiled, prepared like yucca, cooked in a stew with peppers, prepared in soups and broths with rice and/or cabbage, or ground with salt to consume with coffee (Seminario, 2004b). One way to prepare roots is to finely grate or ferment them, and then boil them twice to remove the astringent ingredients (Seminario, 2004b). Some people prefer to eat it cold since the astringent ingredients give it a heat of its own (Seminario, 2004b); however, it was not clear to us if this applied to the leaves in salads or the roots.

Taste tests in Cajamarca, serving roots with the fish dish ceviche and sweet potato or yucca, met with general approval (Seminario, 2004b). Peeled roots were broken up and air dried, making them suitable to add to flour (Seminario, 2004b). Roots could also be peeled then used fresh, described with the phrase "leave them in a milky liquid," and then washed to remove the astringents (Seminario, 2004b). This apparently means to leach the astringents from fresh roots out in water prior to cooking, though this did not necessarily preclude changing the cooking water.

\section{Use of M. expansa for Fodder}

Mature leaves were used as fodder for livestock (Popenoe et al. 1989; CIP 1998). Leaves of $M$. expansa have been reported to contain up to $17 \%$ protein (Flores et al., 2003; Kritzer Van Zant, 2016a), and this protein is considered among the more digestible from plant sources which grow in the Andean highlands (Flores et al. 2003). Leaves have been used for rabbit forage in Peru, giving superior weight gain when compared with a mixture of rye grass (Lolium multiflorum) and clover (Trifolium repens), and the same is seen with whole plants fed to vicuna, reported by (Rea, 1992*; Seminario, 2004b).

By 6.5 months, plants grown two years at high altitudes typically produce $7 \mathrm{~kg}$ each of fodder, these were the same plants 
that produced 0.5 to $2 \mathrm{~kg}$ of roots (Rea, 1994). Seminario (2004b) also reports yields of $7 \mathrm{~kg}$ of fodder per plant. Forage was estimated at about $5.5 \mathrm{~kg}$ per plant in the densely planted experiment in the Valley of Cajamarca (Seminario, 2000c, 2004b).

\section{Marketing of M. expansa}

In Peru, M. expansa roots were only found for sale in the market in Huamachuco, under the name "yuquitas" (Seminario, 2004b). Most are grown for private consumption though they may also be traded or exchanged (Seminario, 2004b). In Bolivia roots are found in rural markets but not in cities (Seminario, 2004b).

\section{Additional Nutritional Data for M. expansa}

Peruvian mauka has a phosphorous content of $117 \mathrm{mg} / \mathrm{gram}$ yet the plants are low in sodium and iron (Rea, 1994). There are no methods presented for assessing sodium and iron content reported by Rea. Calcium levels in the plant, though reported as very high, are considered mostly unavailable as most are in the form of calcium oxalate raphides (Flores et al. 2003). Our observations indicate that this is true, as mature plants are packed with raphides in all tissues, seen in cross sections of roots, leaves and stems under a light microscope. There are two summary tables (Tables 1 and 2 ) of previously published nutritional information for M. expansa in the Supplemental Material for this paper. Both compilations are original to Kritzer Van Zant (2016a). Again, this information was only given for the crop at the species level. We standardized units in these tables when possible to do so. Table 1 examines reports of Humidity/Moisture, Ash, Protein , Fat, Carbohydrates and Fiber, distinguishing between wet and dry material and plant part when possible, from several sources. Table 2 similarly compares reports of mineral content, including as categories calcium, phosphorous, iron and sodium also reported from several sources.

Though M. expansa does not have outstanding numbers for any single amino acid, it does contain all essential amino acids, most other amino acids as well, and is high for total protein relative to other plant protein sources considered (Kritzer Van Zant, 2016a). It should be noted that peeled roots may not be as nutritious as whole roots. All of the amino acid tests in Kritzer Van Zant (2016a) combined root epidermises with root interiors. None of the information on nutrition from the prior literature described the presence or absence of the root epidermes when tests were performed, even though it appears that roots were peeled at least prior to boiling and before traditional drying.

\section{Pests, Disease, and Resistance in the Crop}

Mauka roots are prone to spoil in storage unless refrigerated or desiccated (Seminario, 1993, 2004b). A fungus rot is known to attack roots after harvest, thought to enter wounds in roots and stems resulting from harvesting (Seminario, 1993). A Fusarium sp. is known to attack the root in soils with excess humidity, spreading upward from root tips to the base of the plant in keeping with rising water tables, and affecting the dark green morphotypes most heavily, as seen in the mid 1990s (Seminario, 2000c, 2004b). No viruses were known for M. expansa before 1993, when Phase I of the Collaborative Program for Biodiversity of Andean Roots and Tubercles (Programa Colaborativo de Biodiversidad de Raíces y Tubérculos Andinos) began (Lizárraga, 2000). M. expansa was found to be host to the mosaic virus Mirabilis potyvirus 1 (Mir-1), transmitted by aphids, which systematically deforms leaves of $C$. quinoa, upon evaluation in the laboratory with NCM-ELISA (Lizárraga, 2000, 2004). C. quinoa is presumably Chenopodium quinoa Willd. (Chenopodiaceae).

Mirabilis mosaic caulimovirus (MiMV), also vectored by aphids, was found to cause disease in two Mirabilis species, including mosaic and chlorosis in M. jalapa L., and intervenal infection, rings, and necrosis in M. nyctaginea (Michx.) MacMill. (Lizárraga, 2000, 2004). However, serology and affected crops were not listed for MiMV (Lizárraga, 2000, 2004). In contrast, in laboratory studies conducted by Rolando Estrada at Universidad de San Marcos in Lima, Peru, chago ribosome inhibiting protein has been shown to also offer potential as a low cost biological control against potato viruses including PVX, PVY, and PSTVd (Seminario, 2004b).

Discussion of $M$. expansa protein research (Kritzer Van Zant, $2016 a$ ), includes a reference by Seminario (2004b) to an anonymous 1966 document which seems to be about research on $M$. expansa and M. multiflora Type I ribosome inhibiting proteins (RIPs). RIPs were discovered by Flores, Vivanco and their coauthors. These proteins were also shown by Flores and colleagues to be in M. jalapa, though each species has its own specific RIPs.

In February 2012 in the HRC (Horticultural Research Center) greenhouse at Southern Illinois University, stem cuttings of both varieties ' $T$ ' and ' $L$ ', grown under mist, developed black rot at the tips of emerging leaves about seven days after starting the cuttings, which then spread and destroyed many of the plants. This had not been seen by us before, and may have originated from un-sterilized vermifuge in the starting mix. Plants were quickly removed from the mist bench, yet continued to deteriorate. A few days later, the plants were sprayed heavily and the medium they were growing in drenched with a mild hydrogen peroxide solution at about $0.5 \%$. A few days later still, many plants continued to die but some had improved. A decision was made to wait a few more days and if the rot was still present, destroy all of the plants. When the plants were destroyed, it was realized that most of the recovering plants were var. ' $T$ ', the majority of var. ' $T$ ' plants were recovering, only a small number of var. ' $L$ ' plants had improved, and nearly all var. ' $L$ ' plants were dead. All of the plants were destroyed rather than risk transferring the infection to other soils.

No pests were considered to have serious economic repercussions after ten years of continuous cultivation of $M$. expansa in Peruvian field trials, though the purple flowered morphotypes are most susceptible to problems (Seminario, 2004b). Adult moths of the family Cosmopterigidae feed on M. expansa buds (Seminario, 1993, 2000c, 2004b). Unspecified Lepidoptera spp. larvae attack stems, and suck the sap from leaves (Seminario, 1993, 2004b). A butterfly, thought to be in the Siphingidae group, eats the leaves (Seminario, 1993, 2004b). Rootworm, 
thrips and aphids are minor pests (Seminario, 1993, 2004b).

Damage from Lepidoptera was observed by us on both varieties ' $T$ ' and ' $L$ ' in the field in southern Illinois. Occasionally there have been problems with both aphids and thrips in the greenhouse in southern Illinois. Unidentified pests have consumed tender leaves of young plants in the field during the growth trials in southern Illinois.

\section{Discussion}

Chia et al. (2006)'s concept of eight genetic variants are difficult to compare with the morphotypes in the collections described by Seminario, and colleagues above, or with varieties ' $L$ ' and ' $T$ '. In light of M. expansa's propensity for morphological variation for the same kinds of structures, seen even on individual herbarium specimens, and after growing varieties ' $L$ ' and ' $T$ ', it is very easy to believe that some varieties of the crop may be epigenetic variants.

There is a great deal of disagreement in keys and descriptions by taxonomists, concerning the limits of Mirabilis species for purposes of identification, and Andean Mirabilis is no exception. This includes keys by Paul Clark Standley (1931 b), Antoine Heimerl (1934), and Bittrich and Kühn (1993). Disagreement is also common among publications by the same authors, including Heimerl (1889, 1897, 1934) and Standley (1909, 1918, 1931a, $1931 \mathrm{~b})$. Bittrich and Kühn did not produce an additional key for the Nyctaginaceae. This does not mean Chia et al. (2006) are incorrect in their RAPD analysis, but that there should be other considerations besides their data in protecting biodiversity for this crop. Mirabilis spp. are notorious for reported variation in chromosome numbers so chromosome counts reported in Seminario, (200b) may not hold up for all varieties. Ploidy may be a major factor in distinguishing some varieties of the crop, as is well known for several other crops including wheat and cotton.

Perhaps variation in flowering cycles is a question of the age of the plants, or need for a companion organism such as a mycorrhizal fungus or bacterium to be present to trigger the flowering response. In the greenhouse this could also have been a response in part to lights on some groups of neighboring plants, a situation which was frequently in flux in southern Illinois. All of this is speculation, awaiting future research.

High susceptibility to water should limit $M$. expansa's ability to be invasive in many habitats, though aggressiveness may be a problem in some agricultural settings. USDA does not include M. expansa in its listings for invasive species which is why it could be legally brought into the U.S. Our acquisition of seeds of var. ' $L$ ' from CIP in Peru was greatly delayed by the need to get an official letter, graciously sent by a USDA official directly to CIP, saying that there were no restrictions for bringing $M$. expansa into the United States. Documentation was necessary for the cooperating governments and agencies in Peru to release plant material for export. CIP finally accepted the letter in lieu of a USDA approved permit which CIP requires to release seeds to the United States. USDA officials were initially reluctant to produce a letter that they deemed unnecessary, delaying import of the seed for an additional year.

Since that time, David A. Lightfoot of Southern Illinois Univer-
sity-Carbondale requested seeds of other varieties from CIP. However, CIP did not send them. Perhaps this is due to biodiversity treaty concerns, which have become an issue amongst Andean countries as well as other developing nations. Also, perhaps seeds were not sent because Peruvian researchers had started to publish their own research on M. expansa, since the var. ' $L$ ' seeds were first received in southern Illinois. Possibly, the southern Illinois research has sparked more intense interest in these plants in their home range. Hopefully this is so.

Difficulty in storing fresh roots may also be another reason why indigenous people typically dry them. Correlation between harvest weights and more frequent weeding may have been due to the greater humidity and intensive weed growth in the southern Illinois climate versus the arid regions in the Andes.

Class I ribosome inhibitors (Vivanco et al., 1999) are thought to be safe for humans and other mammals to eat (Vivanco, personal communication, 2009). However, to our knowledge, there is no published tests addressing the safety of any Mirabilis ribosome inhibiting proteins for consumption.

Roots of both cultivars, grown in the southern Illinois plots, and then dried at least eight days, were cooked until they fell apart with other vegetables and quinoa, resulting in a pleasant flavored soup not much different in flavor from similar soup made without the mauka. Our first batch of soup made with an $M$. expansa root included the root epidermis, and was completely palatable and digestible. It should be added that only one small dried root was used in a large pot of soup. A second batch of similar soup, kept on a stove top in warm weather, developed a distinct fermented-lemony flavor after a couple of days of insufficient reheating. At that point the second batch had to be disposed of as it caused extreme indigestion.

Freeze dried roots of a greenhouse-grown var. ' $L$ ' plant, while being ground in preparation for methanol extraction (Kritzer Van Zant, 2016a), gave off a pleasant fragrance reminiscent of pancake or cake batter with vanilla and spices included. All other batches ground to an innocuous odor, more typical of plain flours or starches. Perhaps mauka or at least some of its varieties will prove most useful in today's world cured, ground, dried and then added to flour to enrich the protein and mineral content of baked goods and pasta. Also, it may be that peeling the roots before drying them will help with reducing the astringent flavor, though this would not be the case if the astringent taste is due to the presence of calcium oxalate in the form of raphides. Our observations of thin root sections mounted on microscope slides, showed raphides are present in large numbers in the starchy interior of the roots as well as on and in all structures of these plants.

Interestingly, the $M$. expansa starch gave our soup a silky texture and did not separate from the water even when left out overnight. Most likely the small size of $M$. expansa starch molecules allowed them to remain in suspension. This property may be of industrial use. M. expansa starch samples sent for evaluation to Thailand were considered comparable to cassava starch (Triwitayakorn, personal communication, 2016). However, removing or otherwise mitigating calcium oxalate will again be an issue for production. Lack of an archeological record for $M$. expansa may be due to the limits of archeological methods for 
finding minute starch grains (Kritzer Van Zant, 2016a,b).

Seed grown potato yields measured from 1999 to 2004 in Idaho were reported by Olsen (2004), and include the lowest reported yield of 8.4 tons/hectare for variety Shepody, to 42.4 tons per hectare for the high yielding variety Yukon Gold. These numbers for potatoes are within range of and much higher than for Shepody, though somewhat lower than for Yukon Gold, than the 12-52 tons per hectare reported by Rea (1994) for an unspecified variety or varieties of $M$. expansa. Most likely, M. expansa was grown with considerably less water and fertilizer than is needed for potatoes grown anywhere. However, Rea's yields for M. expansa roots may be the result of two years of growth compared with one season for the potatoes, so the comparability of the yields and costs of production remain to be seen. Also, the yields for the same varieties of potatoes could be lower or higher had they been grown in the same location and conditions as the M. expansa described by Rea (1994). However, even if M. expansa did gave a lower annual yield for its roots than Yukon Gold, unlike potatoes, it can produce a fodder crop at the same time.

Using Seminario's (2000c, 2004b) estimate of 103 plants per hectare would give a potential yield of $721 \mathrm{~kg}$ of fodder per hectare over a single extended growing season, in addition to a root yield of 6-26 tons of roots per hectare averaged per year based on Rea (1994). Putnam, Summers and Orloff (2007), evaluated improved fodder yields for alfalfa grown in California's central valley, low and high desert, and coastal and intermountain regions. They reported forage yields for alfalfa ranging from about five to approaching eight tons per acre in 2004 and 2005 (Putnam et al., 2007). Using the USDA Forest Service Units Conversion Calculator (provisional) (USDA Forest Service, 2004), this becomes 0.32 tons/acre for M. expansa, a considerably lower yield than for improved alfalfa. However, alfalfa is a heavy feeder which prefers rich soils, and requires considerable fertilizer and 2.6 to 6 acre feet of water per year plus often more water to deal with salinity, and is limited by the availability of water for irrigation (Putnam et al., 2007). M. expansa requires almost no assistance with obtaining water, and appears to prefer soils generally considered less fertile (Kritzer Van Zant, 2016a). In addition, the fodder crop is a bonus to the root crop or visa-versa.

Unimproved western U.S. range lands in Utah typically yield $384.83 \mathrm{lbs} /$ acre of forage in the fall/winter late October to January season (Perry 2012). Converting pounds to tons gives .19 tons/acre of forage, only $59 \%$ of the projected six month yield for M. expansa grown at a paramo location, which is high altitude cold desert. It must be conceded that this is for a considerably shorter growing season than for the fall/winter Utah range land, and details of fertilizer and watering are not specified. Still the point is made that $M$. expansa, even when planted for a root harvest, has the potential to be a valuable addition to fodder resources on marginal land, and based on Kritzer Van Zant (2016a) with a minimal input of water and resources, simultaneously producing quantities of fodder at least comparable to unimproved range land in Utah.

Yields from the densely planted Cajamarca experiment (Seminario, 2000c, 2004b) multiply to $137.5 \mathrm{~kg} /$ hectare of fodder from M. expansa. Converting this $137.5 \mathrm{~kg} /$ hectare with USDA Forest Service (2004), gives 61.3 tons/acre of fodder from M. expansa, more than 7.5-12 times the 5-8 tons/acre reported for improved alfalfa in California (Putnam et al., 2007). This is also more than 320 times Perry's (2012) estimate of 0.19 tons/acre for fodder from winter season unimproved Utah range land. These numbers are more than enough to be impressive over a possibly shorter growing season. We must also consider both the high protein quality and quantity in M. expansa fodder as well as how to mitigate the high amounts of calcium oxalate. This should be examined even though there does not appear to be a history of harm to a wide variety of Andean livestock, from eating mature $M$. expansa leaves.

Perhaps the discrepancy in cured vs. fresh consumption depends on whether or not the variety is sweet, or at least less astringent than varieties which are always cured prior to eating. Perhaps, processing for M. expansa developed alongside or from methods applied to other Andean crops. Possibly varieties ' $L$ ' and ' $T$ ', originating as far as we know separately from Peru and Ecuador respectively, also correlate to bitter and sweet versions of the crop in the same manner well known for crops such as cassava. Cassava is also known as manioc (Manihot esculenta (Euphorbiaceae) Crantz). However, it should be considered that M. expansa var. ' $T$ ' was collected by us in Ecuador from a person who cured the roots prior to consumption, seemingly in contradiction to the concept of Ecuadorian roots being sweet instead of astringent.

Interior tissue is difficult to separate from the thin epidermes on dry roots, making them as difficult to peel as dried ginger. Had we known that roots are typically peeled prior to consumption, before doing our research, we would have peeled them prior to drying and testing, or tested both ways.

Var. ' $T$ ''s ability to recover more readily than var. ' $L$ ' in the greenhouse in southern Illinois, makes the point that specific resistance to disease may be different in different varieties of $M$. expansa and that this is worth further investigation. Conversely it may be an indirect effect, as the var. ' $T$ ' material may root faster. Yet, rapid growth may have been due all or in part to the maturity and amount of stored resources in the stem material utilized for propagation. This could further be interpreted two ways. If the starting material for one variety was more mature than most of what was used for starting the other variety, did it need time to dedifferentiate before rooting, or would more stored reserves cause it to root faster? One thing is certain, none of the published research to date, on the effect of $M$. expansa proteins on disease causing organisms, distinguished between varieties of $M$. expansa.

\section{Conclusion}

As a result of examining these documents a clearer image emerges of use, consumption and interest in $M$. expansa in its home range. Comparisons could therefore be drawn with our observations and data from southern Illinois. In addition, published information on other root and forage crop yields, when compared to results from Andean researchers with mauka, point to the reasons why it makes sense to continue examining $M$. ex- 
pansa's potential as a modern food source and cash crop, both in and outside the Andes. Consideration should be given to M. expansa for more extensive genetic, nutrition and agricultural studies. Greater attention should also be given to conserving both wild and domesticated germplasm of this crop. We recommend utilizing the broadest reasonable taxon concepts for distinguishing horticultural varieties of mauka. Currently, those would be the traditional indigenous crop variety concepts. Finally, we believe there are great opportunities to develop new varieties of M. expansa for use throughout the world in places where soils drain rapidly. As for all introduced crops, M. expansa should only be grown where it is unlikely to become a threat to endangered species and ecosystems. M. expansa's extreme susceptibility to standing water will assist with keeping it in check, making it even more desirable for development as a modern crop.

\section{Mirabilis expansa History Review Author Contributions}

All conceptualization, research on source material, interpretation of information and writing for this paper are by Miriam Kritzer Van Zant. This includes translation from sources published in Spanish, and any interpretation and updating of Latin names.

\section{References}

Arbizu C, and M Tapia (1994, 1998) Andean tubers. In: JE Hernándo Bermejo, J León (eds.) (1994) Neglected Crops: 1492 from a Different Perspective; Plant Production and Protection Series No. 26. FAO, pp. 149-163. updated 13 May 1998, downloaded 28 Feb 2011 from: http://www.hort.purdue.edu/newcrop/1492/tubers.html.

Bittrich V, and U Kühn (1993) Nyctaginaceae. In: Kubitzki K, LG Rohwer, and $\vee$ Bittrich (eds.) The families and genera of vascular plants; II flowering plants; Dicotyledons. Springer-Verlag, pp. 473-486.

CIP (Centro Internacional de la Papa) (1998) Useful roots \& tubers; Publication/Annual Report downloaded 7 Mar 2011 from: http:// www.cipotato.org/publications/annual_reports/1998/061.asp.

Chia W, A Julio, B Lopez, F César, S Blas Raúl, et al (2006) Diversidad Genética Molecular de Mirabilis expansa Mediante RAPD: Molecular Genetic Diversity of Mirabilis expansa Using RAPD. Ecol Apl 5 (1, 2): 81-86. Downloaded 25 Jan 2012 from: www.scielo.org.pe/ scielo.php?script=sci_arttext\&pid $=S 172622162006000100011$.

Flores HE, TS Walker, RL Guimarães, HP Bais, and JM Vivanco (2003) Andean Toot and Tuber Crops: Underground Rainbows. HortScience 38(2): 161-167, downloaded 7 Jan 2011 from: http://lamar.colostate.edu/ jvivanco/papers/Hort Science/2003.pdf.

Heimerl A (1889) Nyctaginaceae. In: A Engler, K Prantl (eds.) Die natürlichen Pflanzenfamilien nebst ihren Gattungen und wichtigeren Arten insbesondere den Nutzpflanzen...; Teil 3, 1. Hälfte. Wilhelm Engelmann, Leipzig, pp. 14-32.

Heimerl A (1897) Beiträge zur systematik der Nytaginaceen; SeparatAbdruck aus dem XXIII. Fahresberichte der k. k. Staats-Oberrealschule im XV. Bezirke von Wien (Fünfhaus), $68 \mathrm{Pp}$.

Heimerl A (1934) Nyctaginaceae. In: A Engler, K Prantl (eds.) Die natürlichen pflanzenfamilien, ed. 2, Band 16c. Duncker \& Humboldt, Berlin, pp. 86-134.

IPNI (International Plant Names Index) (2012) utilized for author names for all plant species mentioned besides $M$. expansa, downloaded from frequently: http://www.ipni.org/index.html.

Izquierdo J, and W Roca (1998) Under-utilized Andean food crops: Status and prospects of plant biotechnology for the conservation and sustainable agricultural use of genetic resources. ActaHortic 457(20): 8.

Kritzer Van Zant M (2016a) Analysis and development of Mirabilis expansa (Ruiz and Pav.) Standl.; For potential as a new root crop outside the Andes (Doctoral Dissertation). ProQuest Dissertations and Theses. (Accession Order No. 12694)

Kritzer Van Zant M (2016b) Review of the Economic and Ethno-botany of the Family Nyctaginaceae. Atlas J Biology 2016. In Press.

Lizárraga C (2000) Fascículo 5 Virus en raíces Andinas. In: Seminario Cunya J (ed) Raíces Andinas manual de capacitation. CIP, pp. 1-4.

Lizárraga C (2004) 9 Virus en raíces Andinas. In: Seminario Cunya J (ed) Raíces Andinas: Contribuciones al conocimiento y a la capacitation; Serie: conservación y uso de la biodiversidad de raíces y tubérculos Andinos: Una década de investigación para el desarrollo (1993-2003) No. 6. Universidad Nacional de Cajamarca, Centro Internacional de la Papa (CIP), Agencia Suiza para el Desarrollo y la Cooperación, Lima, Perú, pp. 123-125.

ODA (Oregon Department of Agriculture) (2011) Macfarlane's four o'clock (Mirabilis macfarlanei). Downloaded 25 Feb 2012 from: egov.oregon.gov/ODA/PLANT/CONSERVATION/profile_mima. shtml, moved by Mar 182016 to: http://www.oregon.gov/ODA/ shared/Documents/Publications/PlantConservation/MirabilisMacfarlaneiProfile.pdf.

Olsen N (2004) Seed Potato Performance. University of Idaho, USDA Research, Education \& Economics Information System. Downloaded 22 Feb 2016 from: http://www.reeis.usda.gov/web/ crisprojectpages/0183486-seed-potato-performance.html.

Perry A (2012) A Rough, Tough Forage for Range Land Cattle. United States Department of Agriculture AgResearch Magazine, uploaded Jan 2012, downloaded 22 Feb 2016 from: http://agresearchmag. ars.usda.gov/2012/jan/cattle.

Popenoe H, SR King, J León, and LS Kalinowski $(1989,1990)$ Mauka. In: Vietmeyer ND (ed) Lost crops of the Incas; Little-known plants of the Andes with promise for worldwide cultivation. National Academies Press, Washington, D.C., Pp. 74-81, 331, downloaded 24 Jan 2012 from: http://www.nap.edu/openbook/030904264X/html/'74,html [download not still available], downloaded 29 Feb 2012 from: www.nap.edu/openbook.php? record_id=1398\&page $=74$.

Putnam DH, CG Summers, and SB Orloff (2007) Alfalfa production systems in California. In: CG Summers, DH Putnam (eds.) Irrigated alfalfa management for Mediterranean and desert zones; Chapter 1. University of California Agriculture and Natural Resources Publication 8287, Oakland, downloaded February 22, 2016 from: http:// alfalfa.ucdavis.edu/IrrigatedAlfalfa/pdfs/UCAlfalfa8287ProdSystems_free.pdf.

Rea J (1982) El Miso Una Contrabución de la Agricultura Pre-Inca de Ecuador y Bolivia. Desde el Surco 5: 23-26.

Rea J (1994) Andean roots. In: JE Hernández-Bermejo, and J León (eds.) Neglected crops: 1492 from a different perspective. FAOUN, Rome, and Botanical Garden of Córdoba, Andalusia, Spain, downloaded 17 Jan 2001 and 24 Jan 2012 respectively from: http://www.hort.purdue.edu/newcrop/1492notes.html and www. fao.og/docrep/T0646E00/htm.

Rea J, and J León (1965) La Mauka (Mirabilis expansa Ruiz \& Pavon), Un Aporte de la Agricultura Andina Prehispanica de Bolivia. Anales Cientificos 3: 38-41.

Seminario Cunya J (1993) Aspectos Etnobotanicos y Morfologicos del Chago, Miso o Mauca (Mirabilis expansa R. y P.) en el Peru. Boletín de Lima 15(86): 71-79.

Seminario Cunya J (1994) Chapter 26 Aspectos etnobotánicos y productivos del chago, miso o mauka (Mirabilis expansa (Ruíz y Pavón) Standley. In: Seminaro Cunya, J (ed) Raices Andinas contribuciones 
al conocimiento y a la capacitación; Chapter VI. Mauka (Mirabilis expansa). Universidad Nacional de Cajamarca, Cajamarca, Perú, pp. 367-377.

Seminario Cunya J (2000a) Fascículo 1 Origin de las raíces Andinas. In: Seminario Cunya J (ed) Raíces Andinas manual de capacitation. Centro Internacional de la Papa (CIP), pp. 1-8, 34-36.

Seminario Cunya J (2000b) Fascículo 26 Botanica del chago, miso o mauka, Mirabilis expansa (Ruíz y Pavón) Stanley. In: Seminario Cunya J (ed) Raíces Andinas manual de capacitation. Centro Internacional de la Papa (CIP), pp. 5-6.

Seminario Cunya J (2000c) Fascículo 27 Aspectos etnobotanicos y productivos del chago, miso o mauka, Mirabilis expansa (Ruíz y Pavón) Standley. In: Seminario Cunya J (ed) Raíces Andinas Manual de Capacitation. Centro Internacional de la Papa (CIP), pp. 1-9.

Seminario Cunya J (2004a) 17 Notas sobre etnobotanico de la arracacha (Arracacia xanthorriza Bancroft) en el norte de Peruano. In: Seminario Cunya J (ed) Raíces Andinas: contribuciones al conocimiento y a la capacitation; Serie: Conservación y uso de la biodiversidad de raíces y tubérculos Andinos: Una década de investigación para el desarrollo (1993-2003) No. 6. Universidad Nacional de Cajamarca, Centro Internacional de la Papa (CIP), Agencia Suiza para el Desarrollo y la Cooperación. Lima, Perú, pp. 244-245.

Seminario Cunya J (2004b) 26 Aspectos etnobotanicos y productivos del chago, miso o mauka (Mirabilis expansa [Ruíz y Pavón] Standley). In: Seminario Cunya J (ed) Raíces Andinas: Contribuciones al conocimiento y a la capacitation; Serie: Conservación y uso de la biodiversidad de raíces y tubérculos Andinos: Una década de investigación para el desarrollo (1993-2003) No. 6. Universidad Nacional de Cajamarca, Centro Internacional de la Papa (CIP), Agencia Suiza para el Desarrollo y la Cooperación. Lima, Perú, pp. 367-376.

Seminario Cunya J, and M. Valderrama (2004) 14 Conservación de germplasma de arracacha con campesinos. In: Seminario Cunya J (ed) Raíces Andinas: Contribuciones al conocimiento y a la Capacitation. Serie: Conservación y uso de la biodiversidad de raíces y tubérculos Andinos: Una década de investigación para el desarrollo (1993-2003) No. 6. Universidad Nacional de Cajamarca, Centro Internacional de la Papa (CIP), Agencia Suiza para el Desarrollo y la Cooperación. Lima, Perú, 180 pp.

Sperling CR, and SR King (1990) Andean tuber crops: Worldwide potential. In J Janick, and JE Simon (eds.) Advances in New Crops. Timber Press, Portland, OR, pp. 428-435, downloaded 17 Oct 2001 from: http://newcrop.hort.purdue.edu/newcrop/proceedings $1990 / \mathrm{VI}-428 . \mathrm{html}$.

Standley PC (1909) The Allioniaceae of the United States with Notes on Mexican Species. In: FV Coville (ed) Contributions from the United States National Herbarium; Volume XII, Part 8. Government Printing Office, Washington, $389 \mathrm{pp}$.

Standley PC (1918) (Chenopodiales) Allioniaceae. North American Flora 21 (3): 171-254.

Standley PC (1931a) Studies of American plants V. Field Museum of Natural History Botanical series publication 294; vol. VIII, No. 5. Field Museum, Chicago, pp. 304-311.

Standley PC (1931b) The Nyctaginaceae and Chenopodiaceae of Northwestern South America. Field Museum of Natural History Pub- lication 303 Botanical Series 11 (3): 73-114.

Tapia ME (1990) Capitulo I Origen y domesticacion de las especies alimenticias en la region Andina. In: Tapia, ME (ed) Cultivos Andinos subexplotados y su aportea la alimentacion. Organizacion de las Naciones Unidas para la Agricultura y la Álimentacion, FAO, pp. 20, 27, 106-107.

Standley PC (2007) The role of under-utilised plant species with regard to increased food security and improved health of poor people, in mountain regions. Institu Project HAP-PNUD/Peru. White paper, p. 4, uploaded 2007, downloaded 24 Jan 2012 from: www.uderutilized-species.org/documents/PUBLICATIONS/m_t.pdf.

Túpac Yupanqui A (2000) Fascículo 11 Poscosecha de las raíces Andinas con en el manejo del producto fresco. In: Seminario Cunya J (ed) Raíces Andinas manual de capacitation. Centro Internacional de la Papa (CIP), pp. 2, 6-7.

Ugent D, and C Ochoa (2006) La etnobotánica del Perú: Desde la prehistoria al presente. Consejo Nacional de Ciencia, Tecnología e Innovación Tecnológica, CONCYTEC, Lima, Perú, 403 Pp.

USDA Forest Service (2004) Units conversion calculator (provisional). Rocky Mountain Research Station, Moscow, ID 83843, uploaded 22 Jul 2004, downloaded 22 Feb 2016 from: http://forest.moscowfsl.wsu.edu/engr/software/convert.html.

Valderrama M, and J Seminario Cunya (2004) 4 Conservación ex situ de germplasma de cuatro raíces Andinas: Chago, yacón, achira y arracacha. In: Seminario Cunya J (ed) Raíces Andinas: Contribuciones al conocimiento y a la capacitation; Serie: Conservación y uso de la biodiversidad de raíces y tubérculos Andinos: Una década de investigación para el desarrollo (1993-2003) No. 6. Universidad Nacional de Cajamarca, Centro Internacional de la Papa (CIP), Agencia Suiza para el Desarrollo y la Cooperación, Lima, Perú, pp. 68-75.

Vásquez N, C Medina, and M Lobo (2004) 13 Caracterización morfológica de la collección Columbiana (Tolima, Huila, Boyaca, Cauca) de arracacha (Arracacia xanthorrhiza). In: Seminario Cunya J (ed) Raíces Andinas: Contribuciones al conocimiento y a la capacitation; Serie: Conservación y uso de la biodiversidad de raíces y tubérculos Andinos: Una década de investigación para el desarrollo (19932003) No. 6. Universidad Nacional de Cajamarca, Centro Internacional de la Papa (CIP), Agencia Suiza para el Desarrollo y la Cooperación, Lima, Perú, p. 177.

Vivanco JM, D Weitzel, and HE Flores (1997) Characterization of a major storage root protein isolated from the Andean root crop species Mirabilis expansa. In: HE Flores, JP Lynch, D Eissenstat (eds.) Radical biology: Advances and perspectives on the function of plant roots. American Society of Plant Physiologists, pp. 454-457.

Vivanco JM, BJ Savary, and HE Flores (1999a) Characterization of Two Novel Type I Ribosome-inactivating Proteins from the Storage Roots of the Andean Crop Species Mirabilis expansa. Plant Physiol 119:1447-1456.

Vivanco JM, LF Salazar, and M Querci (1999b) Antiviral and Antiviroid activity of MAP-containing extracts from Mirabilis jalapa roots. Plant Dis 83:1116-1121.

Vivanco JM, and HE Flores (2000) Biosynthesis of Ribosome Inactivating Proteins from Callus and Cell Suspension Cultures from Mirabilis expansa. Plant Cell Reports 19: 1033-1039. 


\section{Van Zant, 2016 - Supplementary Data}

Table 1. Nutrition values for roots, stems, foliage and unspecified parts of $M$. expansa from various authors and their sources.

\begin{tabular}{|c|c|c|c|c|c|c|c|}
\hline Mate rial (Wet / Dry) & $\begin{array}{l}\text { Humidity / } \\
\text { Moisture }\end{array}$ & Ash & Protein & Fat & Carbohydrates & Fiber & Source \\
\hline \multirow[t]{2}{*}{ Roots (100 g) } & $59.3 \%$ & $2.2 \mathrm{~g}$ & $4.4 \mathrm{~g}$ & $0.1 \mathrm{~g}$ & $33.1 \mathrm{~g} * *$ & $1.0 \mathrm{mg}$ & Tapia (1990) \\
\hline & & & & & & & Montenegro\& Pebe (1988*) \\
\hline Roots & $59.3 \%$ & -- & $4.4 \mathrm{~g}$ & $0.1 \%$ & $33.1 \mathrm{mg} * *$ & $1.0 \mathrm{mg}$ & Seminario Cunya (2004a) \\
\hline Subterranean parts - Dry & -- & -- & 6.9 & $0.7 \mathrm{~g}$ & $87.0 \mathrm{~g}$ & 1.3 & Seminario Cunya (1993) \\
\hline 7 months & & & & & & & $\operatorname{EEALM}(1972 *)$ \\
\hline Subterranean parts - Wet & 65 & -- & 2.4 & $6.3 \mathrm{~g}$ & $30.5 \mathrm{~g}$ & 0.4 & Seminario Cunya (1993) \\
\hline 7 months & & & & & & & $\operatorname{EEALM}(1972 *)$ \\
\hline Subterranean parts - Wet & -- & -- & 2.5 & -- & $35.0 \mathrm{~g}$ & 6.5 & Seminario Cunya (1993) \\
\hline 7 months & & & & & & & UNC* \\
\hline \multirow[t]{2}{*}{ Subterranean parts - Dry } & -- & 4.20 (\% wt.) & 6.90 (\% wt.) & 0.72 (\% wt.) & 86.90 (\% wt.) & 1.25 (\% wt.) & Seminario Cunya (2004b) \\
\hline & & & & & & & $\operatorname{EEALM}(1972 *)$ \\
\hline \multirow[t]{2}{*}{ Subterrane an parts- Wet } & -- & 1.47 (\% wt.) & 2.40 (\% wt.) & 0.25 (\% wt.) & 30.50 (\% wt.) & 0.43 (\% wt.) & Seminario Cunya (2004b) \\
\hline & & & & & & & $\operatorname{EEALM}(1972 *)$ \\
\hline \multirow[t]{2}{*}{ Subterrane an parts- Wet } & -- & 2.18 (\% wt.) & 4.30 (\% wt.) & 0.09 (\% wt.) & 33.08 (\% wt.) & 0.96 (\% wt.) & Seminario Cunya (2004b) \\
\hline & & & & & & & Montenegro \& Franco (1988*) \\
\hline \multirow[t]{2}{*}{ Stems - Dry } & -- & -- & 17.2 & $5.0 \mathrm{~g}$ & $43.3 \mathrm{~g}$ & 20.8 & Seminario Cunya (1993) \\
\hline & & & & & & & $\operatorname{EEALM}(1972 *)$ \\
\hline \multirow[t]{2}{*}{ Stems - Wet } & 75 & -- & 4.3 & $1.3 \mathrm{~g}$ & $10.8 \mathrm{~g}$ & 5.2 & Seminario Cunya (1993) \\
\hline & & & & & & & $\operatorname{EEALM}(1972 *)$ \\
\hline \multirow[t]{2}{*}{ Foliage - Dry } & $59.39 \%$ & $2.2 \%$ & $4.0 \%$ & -- & $10.0 \%$ & $0.9 \%$ & Seminario Cunya (1993) \\
\hline & & & & & & & UNC \\
\hline \multirow[t]{2}{*}{ Foliage - Dry } & -- & $13.57 \%$ & $17.2 \%$ & $5.04 \%$ & $43.33 \%$ & $20.84 \%$ & Seminario Cunya (2004b) \\
\hline & & & & & & & $\operatorname{EEALM}(1972 *)$ \\
\hline \multirow[t]{2}{*}{ Edible Parts } & -- & $2.2 \%$ & $4.4 \%$ & $0.1 \%$ & $33.1 \%$ & $1.0 \%$ & Seminario Cunya (1993) \\
\hline & & & & & & & Montenegro \& Franco (1988) \\
\hline Unspecified compared $\mathrm{w} / 9$ & -- & -- & $4.3 \%$ range: & $1.3 \%$ & $10.8 \%$ range: & -- & Seminario Cunya (1993) \\
\hline Andean crops & & & $0.7-4.3$ & $\begin{array}{l}\text { range: } 0.1- \\
1.3\end{array}$ & $9.8-32.8$ & & $\operatorname{EEALM}(1972 *)$ \\
\hline Edible part compared w/ 7 & -- & -- & $4.30 \%$ range: & $0.09 \%$ & $33.08 \%$ & $0.96 \%$ & Seminario Cunya (2004b) \\
\hline ( 6 for fats, 4 for fiber) & & & $0.7-4.3$ & $0.09-0.51$ & range: & range: & \\
\hline Andean crops & & & & & $9.8-33.08$ & $0.54-1.10$ & \\
\hline
\end{tabular}

Andean crops

** There is disagreement between Tapia (1990) and Seminario Cunya (2004a) as to whether carbohydrates were given in $\mathrm{g}$ or $\mathrm{mg}$, the numerical values are the same. Units are as given.

Table 2. Mineral values for roots and stems of $M$. expansa from various authors and their sources. Units are all in mg. *** by comparison, must be per $100 \mathrm{~g}$ of roots.

\begin{tabular}{llllll}
\hline Material (Wet/Dry) & Calcium & Phosphorous & Iron & Sodium & Source \\
\hline Roots (100 g) & $283 \mathrm{mg}$ & $111 \mathrm{mg}$ & $0.1 \mathrm{mg}$ & -- & $\begin{array}{l}\text { Tapia (1990) } \\
\text { Montenegro \& Pebe (1988*) }\end{array}$ \\
& & & & & Seminario Cunya (2004a) \\
$\begin{array}{l}\text { Roots*** } \\
\text { Stems - Dry }\end{array}$ & $283 \mathrm{mg}$ & $111 \mathrm{mg}$ & $0.1 \mathrm{mg}$ & -- & $\begin{array}{l}\text { Seminario Cunya (1993) } \\
\text { EEALM (1972*) }\end{array}$ \\
Stems - Wet & $680.0 \mathrm{mg}$ & $150.0 \mathrm{mg}$ & -- & -- & Seminario Cunya (1993) \\
& & $590.0 \mathrm{mg}$ & -- & -- & EEALM (1972*) \\
$\begin{array}{l}\text { Unspecified (100 g) } \\
* * *\end{array}$ & $283 \mathrm{mg}$ & $111 \mathrm{mg}$ & -- & $<0.01 \mathrm{mg}$ & Seminario Cunya (2004b) \\
\hline
\end{tabular}

